\title{
Crafting a beer brand: An intersectionality of logo aesthetic and representation
}

Sarah Frankel, Dr. Stefanie Benjamin \& Dr. Carrie Stephens, University of Tennessee

Keywords: Craft Beer, Brewer's Association, Inclusion, Diversity

\section{Introduction}

According to The Brewers Association ${ }^{1}$ (2020), the United States is home to 6,266 craft breweries ranging from regional, micro, brew, large non-craft and other non-craft with $31.5 \%$ female and $68.5 \%$ male consumers. Recently, the narrative surrounding women and beer has vacillated from sexist representations of women on beer labels and commercials to the obsolete highlighting of female brewers and drinkers in the news as a rare specimen (Land, 2019). The reality is that being a woman in a male dominated beer industry landscape potentially induces stress and anxiety, in addition to creating barriers of entry for female consumers. Consequently, this reality is at the center of the Brewers Association's mission, "to cultivate diversity and inclusion within the brewing community for both industry and consumers" (Brewers Association, 2020). The Brewers Association's website offers resources, grants, and a 'diversity ambassador' (representative who facilitates inclusive craft beer practices and marketing) but there are no discussions around inclusive brand logos or messaging. Therefore, this study will critically examine how diversity and inclusion is portrayed through a critical content analysis of U.S. craft beer brewery logos.

Brand logos and their impact on consumer attitude towards the brand is an increasingly important way to capture awareness and communicate meaning with consumers due to frequency of consumer exposure to the brand (Bossel, Geyskens, \& Goukens, 2019; Cian, Krishna \& Elder, 2014). Logos act as a means of utilizing visual elements to communicate and can be used as a site of representation (Cian et al., 2014). These logos promote emotional responses that allow brands to draw attention from consumers which can facilitate to brand preference; the appearance of a brand is determined by the brand-design, otherwise stated as visual characteristics of the brand, such as the colors, shapes and size (Hulten, 2011). The brand logo becomes an area that communicates with a consumer to quickly inform them on how the brand is different in the market and can trigger an emotional response that allows the consumer to make inferences on the brand's preferences (e.g. if the brand values women). Informed by symbolic interaction, critical perspectives, and feminist perspectives framework (Pitre, Kushner, Raine \& Hegadoren 2013, this study aims to explore the major research questions: (1)What types of images are being represented on craft beer logos and; (2) In what ways do the brand logos address the inclusion and diversity initiatives of the Brewers Association?

\footnotetext{
${ }^{1}$ The Brewers Association is a 501(c)(6) not-for-profit trade association. The association is an organization of brewers, for brewers and by brewers. More than 5,400 U.S. brewery members and 46,000 members of the American Homebrewers Association are joined by members of the allied trade, beer wholesalers, retailers, individuals, other associate members and the Brewers Association staff to make up the Brewers Association.
}

Page 1 of 4

(c) 2020 The author(s). Published under a Creative Commons Attribution License (https://creativecommons.org/licenses/by/4.0/), which permits unrestricted use, distribution, and reproduction in any medium, provided the original work is properly cited.

ITAA Proceedings, \#77 - https://itaaonline.org 


\section{Methods and Interpretation of Data}

From the U.S. Brewers Association website, as a research team, we identified 8,001 beer labels from January 2020 through April 2020. We used an inductive approach and first analyzed the logos following a grounded theory method (Corbin \& Strauss, 1990). We used open, axial, and selective coding and looked for emergent themes throughout (Saldaña, 2016). A single Excel codebook, representing all of the 50 states for the U.S., with code definitions was created and referenced throughout the process. We utilized intensive team discussion, "dialogical intersubjectivity," coder adjudication, and group consensuses as an agreement goal (Brinkmann \& Kvale, 2015; Saldana, 2016; Sandelowski \& Barroso, 2007). Next, we grouped together any codes that we felt were coded in similar ways in order to reduce redundancy. Finally, we finalized the codes that we thematized using theory to assist with the entire process.

Several perspectives were used to inform the analysis of this study. First, symbolic interaction is deeply rooted in the perspective that symbols, such as language, images, self, ideas, and emotions guide lived experiences (Blumer 1969). These symbols influence how an individual may think, interact, react, and contextualize meanings in their own reality (Blumer 1969). Next, a critical perspective was utilized to identify sources of power, alienation, and domination that guide decision making (Kushner and Morrow 2003). Finally, the feminist perspective focuses on life context that assist in identifying inequalities, environments of domination and power, and marginalization (Sprague 2005). Moreover, the feminist perspective is designed to focus on the needs of marginalized communities and to provide individuals opportunities to share their lived experiences (Sprague 2005).

Informed by this framework, the research team's preliminary interpretation of this data $(n=621)$ identified various other themes when analyzing the images. Currently, we have identified four themes; (1) nature, (2) traditional male jobs, (3) the occult, and (4) facial hair. The first major theme that was identified was the use of 'nature'. Examples of this imagery include the sun, moon, animals, hops, grain, and mountains. After coding for element separately, we noticed that at least one of these concepts were represented in $233 \log$ os (37.52\%). Another reoccurring theme centered around 'male imagery' were gendered 'traditional' male 'work roles' such as black smith, ironworker, mining, automotive and electric represented in 60 logos $(9.66 \%)$. The next theme was 'occult' imagery such as death, bones, skulls, and motorcycle culture represented in 51 logos (8.21\%). Finally, the depiction of 'facial hair' on men, skulls, and inanimate objects like a beer bottle were found in $10 \log$ os $(1.61 \%)$. What was also noteworthy about the preliminary exploration is the portrayals of the female form found in the sample $(.64 \%)$ depicted images as caricatures of women such as a flapper, a mermaid, a witch and breasts spilling out of a coreset. Moreover, the tongue in cheek usage of "beaver" was found on three occasions which could also be considered offensive and belittling to female consumers.

\section{$\underline{\text { Discussion }}$}

The Brewer's Association is proactively engaging and providing resources to independent craft beer brewers to adapt more inclusive practices into production and consumption. Though from our preliminary analysis, messages from craft beer logos are not 
aligned with the inclusivity and diversity initiatives of the Brewer's Association. While the use of nature aligns with literature on place identity and craft beer, the conventionally masculine images of traditional blue-collar heteronormative trade and masculine physical features such as facial hair continue to perpetuate beer culture as a male dominated space with little room for additional representation. Given the power of imagery, craft breweries should think through the messages they are sending and whether or not they reflect the women who craft and drink beer, and the inclusivity they are striving to create. This project aims to assist in adding to the toolkit for best practices provided by the Brewer's Association. 


\section{References}

Brewers Association. (2017). https://www.brewersassociation.org/

Bossel, V., Geyskens, K., \& Goukens, C. (2019). Facing a trend of brand logo simplicity: The impact of brand logo design on consumption. Food Quality and Preference, 71, 129-135.

Cian, L., Krishna, A., \& Elder, R. S. (2014). This logo moves me: Dynamic imagery from static images. Journal of Marketing Research, 51(2), 184-197.

Corbin, J., \& Strauss, A. (1990). Grounded theory research: Procedures, canons, and evaluation criteria. Qualitative Sociology. 13(1), 3-21.

Hulten, B. (2011). Sensory marketing: The multi-sensory brand-experience concept. European Business Review, 23(3), 256-273.

Kushner, K.E. and Morrow, R., 2003. Grounded Theory, Feminist Theory, Critical Theory: Toward Theoretical Triangulation. Advances in Nursing Science, 26(1), 30-43.

Land, C. (2019, August 30). Why the beer industry's sexism problem goes much deeper than chauvinistic marketing. Retrieved from https://www.independent.co.uk/life-style/foodand-drink/beer-sexism-marketing-brewers-women-camra-a9081521.html

Pitre, N.Y., Kushner, K.E., Raine, K.D. and Hegadoren, K.M., 2013. Critical Feminist Narrative Inquiry: Advancing Knowledge Through Double-Hermeneutic Narrative Analysis. Advances in Nursing Science, 36(2), 118-132.

Saldaña, J. 2016. The Coding Manual for Qualitative Researchers. Thousand Oaks, CA: Sage Publications.

Sandelowski, M., and J. Barroso. 2003. Creating Metasummaries of Qualitative Findings. Nursing Research 52(4), 226-233.

Sprague J. 2005. Feminist Methodologies for Critical Researchers: Bridging Differences. New York, NY: Al- tamira. 